\title{
Electro-disinfection with BDD-electrodes featuring PEM technology
}

J. Isidro ${ }^{1}$, D. Brackemeyer ${ }^{2}$, C. Sáez ${ }^{1}$, J. Llanos ${ }^{1}$, J. Lobato ${ }^{1}$, P. Cañizares ${ }^{1}$, T. Matthée ${ }^{2}$,

$$
\text { M. A. Rodrigo }{ }^{1, *}
$$

${ }^{1}$ Chemical Engineering Department, Faculty of Chemical Sciences and Technologies, University of Castilla-La Mancha, Edificio Enrique Costa Novella. Campus

Universitario s/n, 13005 Ciudad Real, Spain

${ }^{2}$ CONDIAS GmbH, Fraunhoferstraße 1b, 25524 Itzehoe- Germany

\begin{abstract}
This work reports the use of a special PEM-electrolyzer equipped with diamond anodes for the highly-efficient disinfection of water preventing the formation of chlorates and perchlorates. The cell is a MICROZON ${ }^{\circledR}$ cell manufactured by CONDIAS (Itzehoe, Germany) with a very short hydraulic residence time $\left(0.008 \mathrm{~s}\right.$ for $90 \mathrm{~L} \mathrm{~h}^{-1}$, which is the maximum allowable flowrate) and a polymer exchange membrane electrolyte that separates the anode and cathode into a membrane-electrode assembly. This cell can avoid the formation of significant concentrations of chlorates because of the very short contact time between the water and the electrode that prevents the oxidation of hypochlorite by hydroxyl radicals. In this paper, we report tests in which we demonstrate this outstanding performance even in the worst conditions (low flowrate) and we also explain the differences observed in the operation in continuous and discontinuous mode with the same water.
\end{abstract}




\section{Keywords}

Electro-disinfection; chlorates; perchlorates; electrochemical cells; PEM electrolyzers; diamond

\section{Highlights}

- PEM electrolyzers can be successfully used for disinfection of water

- Cell design is a decisive point for electro-disinfection with diamond electrodes

- More than 6-log pathogens removal with very low electric current charges

- Perchlorates prevented using low water-electrode contact times 


\section{Introduction}

Over the last years, many attempts have been done in order to develop new disinfection processes that help to overcome the important drawbacks of the currently applied technologies. Among these trials, processes based on the use of electrochemistry are worth to mention, because of their very promising results[1, 2].

Electrolysis of water is known to lead to the generation of a cocktail of oxidants from the ions naturally contained, that includes typically at least carbonates, sulfates, chlorides. Thus, the production of low concentration of chlorine and peroxoanions (peroxocarbonates, peroxosulfates) is expected, in addition to other oxygen-based oxidants such as hydrogen peroxide and ozone[3-6]. This cocktail of oxidants may have a very positive impact on the destruction of pathogens and it may help to avoid the important problems associated with the occurrence of hazardous chlorine-based compounds during disinfection. In addition, electrolysis may also attain a mineralization of the organics contained in water avoiding the formation of halo-organics.

In using electrolytic technology for disinfection, there are two keys in order to get efficient processes. The first is the anode used. Among the great variety, diamond coatings are the most interesting[1, 7, 8]. It is true that Mixed Metal Oxides (MMO) anodes are very efficient for the oxidation of chloride to chlorine[8-12]. In fact, a variety of this type of electrode is used in saline disinfection for swimming pools, achieving outstanding performance that made this technology to be in a very high TRL, with many companies selling devices with this purpose[11]. However, this is not what it is expected for electro-disinfection for human supply. In contrast, what it is expected is to minimize the significance of chlorinated disinfectants and to promote the additive effect of the other oxidants that may be produced [13]. In this way, the use of diamond coatings as anodes may help to reach this objective, because of the very high production rate of oxidants. However, this electrode has a major drawback. It is so powerful in the production of 
oxidants that the oxidation of chloride does not stop in the formation of chlorine (with the further disproportionation to hypochlorite) but it continues to produce of chlorates and perchlorates[14-17]. At this point, avoiding the formation of the high valent species has been a major goal for the research of many groups and two strategies have been found to be promising: 1) minimizing the contact time between the diamond anode and the water electrolyzed and 2) adding species in water susceptible to be oxidized by hypochlorite to prevent its further oxidation, with hydrogen peroxide being one of the best options[18]. The second key for an efficient disinfection is the electrochemical cell design[19-22]. Most of the cells used are undivided cells in which the water to be disinfected is the electrolyte. Recently, the good prospects made by a different concept was shown in the literature with the $\mathrm{CabECO}^{\circledR}$ cells, in which the electrolyte is not the water but a polymer exchange membrane that directly connect the anode and the cathode[20, 23, 24]. These cells allow the treatment of very low conductivity water and minimize the production of chlorates.

An evolution of this cell concept is the MICROZON ${ }^{\circledR}$ cell, with the same configuration but a very low contact time between aqueous solution and the electrodes. These cells are designed to prevent the formation of chlorates and perchlorates and are the objective of this work, where we aimed to evaluate its use in the worst operation conditions in order to shed light on their outstanding performance.

\section{Material and Methods}

Electrochemical cells. Electrochemical disinfection tests were carried out in MICROZON $^{\circledR}$ electrochemical cells, especially designed to produce ozone in lowconductivity water and provided by CONDIAS (Itzehoe, Germany). This cell was equipped with two DIACHEM ${ }^{\circledR}$ electrodes (diamond coating on a structured silicon substrate), which are arranged in a membrane electrode assembly with a fumasep ${ }^{\circledR}$ cation 
exchange membrane $\left(15 \times 7.5 \times 0.725 \mathrm{~mm}^{3}\right)$. The cell was connected to the water reservoir by a peristaltic pump and powered by a Promax DC FA-376 power supply and a Keithley 2000 Multimeter was used to monitor the current and cell voltage. In order to increase the Hydraulic Residence Time (HRT) of the fluid when came across the MIKROZON® cell and to study the influence of the configuration of the system, two different strategies were followed:

1) 4 MIKROZON® connected in parallel and operated in continuous mode. In this case, the cells were operated in a single-pass configuration from the tank that contains the raw water to a storage tank for the treated effluent.

2) 1 MIKROZON ${ }^{\circledR}$ operated in discontinuous mode. Here, the solution is constantly circulated through the system from and to the storage tank of the initial solution.

A schematic representation of the cell is included as supplementary material (Fig. 1. Sup).

Characterization. Ions concentrations were measured by ion chromatography using a Metrohm 930 Compact IC Flex coupled to a conductivity detector. A Metrosep A Supp 7 column was used to determine anions, by passing through it a mobile phase consisted of $85: 15 \mathrm{v} / \mathrm{v} 3.6 \mathrm{mM} \mathrm{Na}_{2} \mathrm{CO}_{3} /$ acetone with a flow rate of $0.8 \mathrm{~cm}^{3} \mathrm{~min}^{-1}$. The temperature of the oven was 45 and $30{ }^{\circ} \mathrm{C}$. The volume injection was $20 \mu \mathrm{L}$. Hypochlorite was analyzed by titration with $0.001 \mathrm{M} \mathrm{As}_{2} \mathrm{O}_{3}$ in $2 \mathrm{M} \mathrm{NaOH}$. Microbiological tests conform to standard methods were used: UNE-EN ISO 6222:1999 and UNE-EN 12780:2003 for the quantification of Total coliforms and Pseudomonas Aeruginosa, respectively. The target water treated was directly taken from the inlet of the municipal Water Treatment Plat of Ciudad Real (a surface water from the Gasset reservoir). Due to the absence of significant microbiological pollution, this water was intensified with pure cultures of 
Escherichia coli and Pseudomonas aeruginosa. The average concentration of the tests performed is gathered in Table 1 .

Table 1. Composition of the target water

\begin{tabular}{|c|c|c|c|}
\hline Parameter & Parallel & Discontinuous & Units \\
\hline Total coliforms & $1.31 \mathrm{E}+08$ & $5.50 \mathrm{E}+07$ & CFU $100 \mathrm{~mL}^{-1}$ \\
\hline P. aeruginosa & $3.16 \mathrm{E}+08$ & $2.71 \mathrm{E}+08$ & $\mathrm{CFU} 100 \mathrm{~mL}^{-1}$ \\
\hline $\mathbf{p H}$ & 7.35 & 7.23 & Units \\
\hline Conductivity & 389.5 & 435.3 & $\mathrm{mS} \mathrm{cm}^{-1}$ \\
\hline $\mathbf{N O}_{3}^{-}$ & 6.35 & 0.67 & $\mathrm{mg} \mathrm{L}^{-1}$ \\
\hline $\mathbf{C l}^{-}$ & 40.45 & 53.79 & $\mathrm{mg} \mathrm{L}^{-1}$ \\
\hline $\mathbf{S O}_{4}{ }^{2-}$ & 25.57 & 32.40 & $\mathrm{mg} \mathrm{L}^{-1}$ \\
\hline $\mathbf{N a}^{+}$ & 21.66 & 26.29 & $\mathrm{mg} \mathrm{L}^{-1}$ \\
\hline $\mathbf{K}^{+}$ & 5.21 & 7.99 & $\mathrm{mg} \mathrm{L}^{-1}$ \\
\hline $\mathbf{C a}^{2+}$ & 41.86 & 38.64 & $\mathrm{mg} \mathrm{L}^{-1}$ \\
\hline $\mathbf{M g}^{2+}$ & 21.68 & 11.85 & $\mathrm{mg} \mathrm{L}^{-1}$ \\
\hline
\end{tabular}

\section{Results and Discussion}

Figure 1 shows the time course of the continuous treatment of surface water intensified with microorganisms by four different MICROZON ${ }^{\circledR}$ cells operated in parallel, in order to check the capacity of disinfection and the reproducibility of the technology. In every case the current applied was $1.2 \mathrm{~A}$, the maximum value recommended by the manufacturer for a safe and optimized operation, and the flow rate was changed from 7.5 to $22.5 \mathrm{~L} \mathrm{~h}^{-1}$, values lower than the recommended flowrate for these cells $\left(30-90 \mathrm{~L} \mathrm{~h}^{-1}\right.$ in order to have an optimum turbulence), selected in order to operate in the worst possible conditions trying to see if the production of chlorates can be avoided as it was observed in previous works even when increasing the hydraulic residence time from the recommended value of $0.008 \mathrm{~s}\left(90 \mathrm{~L} \mathrm{~h}^{-1}\right)$ up to almost $0.1 \mathrm{~s}\left(7.5 \mathrm{~L} \mathrm{~h}^{-1}\right)$. In those previous works, concentration of chlorates in continuous disinfection at flowrates higher than 30 
$\mathrm{L} \mathrm{h}^{-1}$ were lower than $1 \mathrm{ppm}$ and concentration of THMs never overpasses the level of 10 $\mu \mathrm{g} \mathrm{L}^{-1}[25]$.

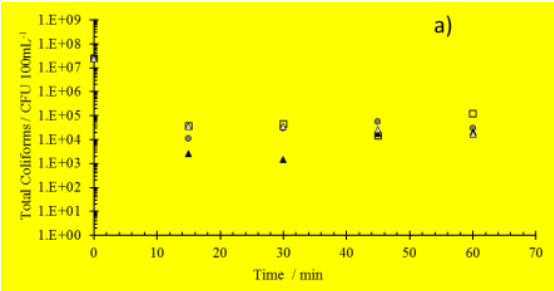

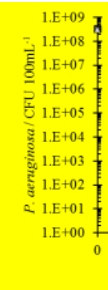

b)
Figure 1. Time course of the concentration of total coliforms (part a) and pseudomonas aeruginosa (part b) during the treatment of $7.5 \mathrm{~L} \mathrm{~h}^{-1}$ of water intensified with microorganisms in continuous mode $\square$ cell 1; $\boldsymbol{\Delta}_{\text {cell } 2 ;} \Delta$ cell 3; $\odot$ cell 4 .

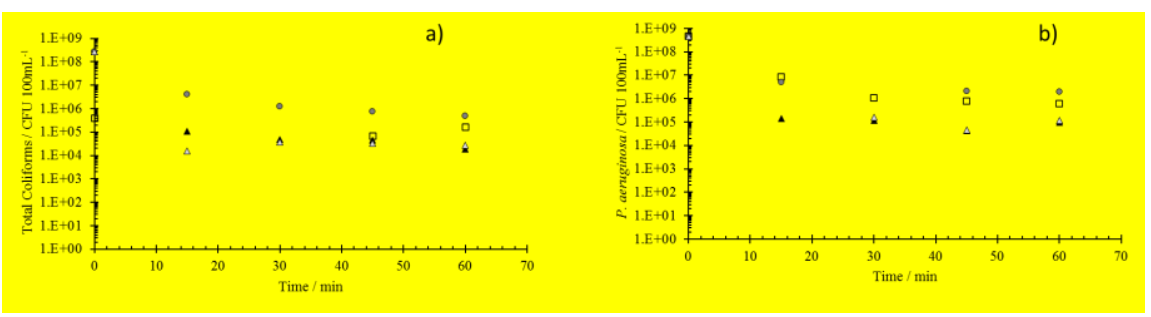

Figure 2. Time course of the concentration of total coliforms (part a) and pseudomonas aeruginosa (part b) during the treatment of $15 \mathrm{~L} \mathrm{~h}^{-1}$ of water intensified with microorganisms in continuous mode $\square$ cell 1; $\boldsymbol{\Delta}_{\text {cell } 2 ;} \Delta$ cell 3; $\bullet$ cell 4 .

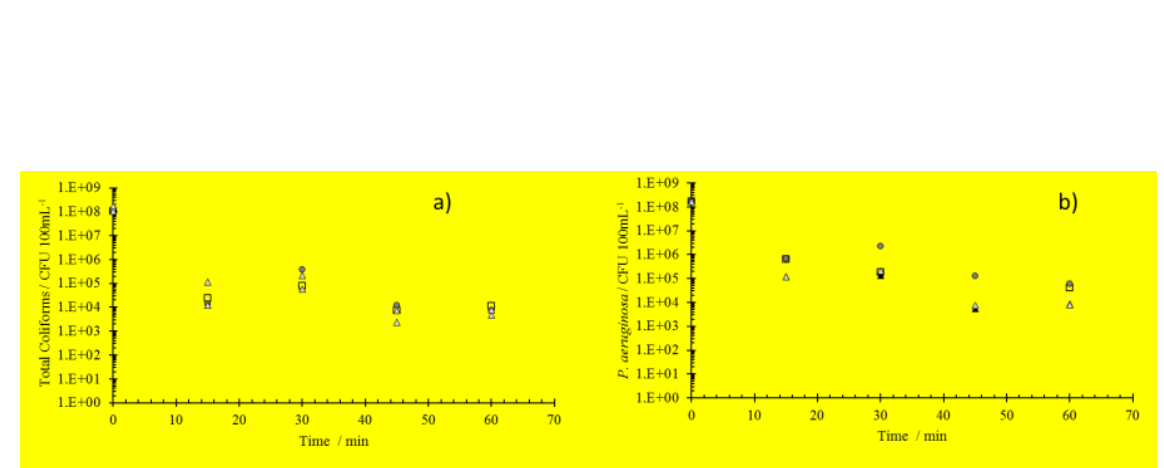

Comentado [JLL1]: Esto creo que está mal. Entiendo que hacemos referencia al artículo: "Operating the CabECOB membrane electrolytic technology in continuous mode for the direct disinfection of highly fecal-polluted water". En ese artículo las concentraciones de clorato que temenos son del orden de $0.005 \mathrm{mM}$, que equivale a unas $0.4 \mathrm{ppm}$, es decir, $400 \mathrm{ppb}$. Lo que se dice en el artículo es que tenemos menos de $10 \mathrm{ppb}$ de THM. Voy a cambiarlo en función de eso, y voy a añadir la referencia. Si no es esa, corregirlo. 
Figure 3. Time course of the concentration of total coliforms (part a) and pseudomonas aeruginosa (part b) during the treatment of $22.5 \mathrm{~L} \mathrm{~h}^{-1}$ of water intensified with microorganisms in continuous mode $\square$ cell 1; $\boldsymbol{\Delta}_{\text {cell } 2 ;} \Delta$ cell 3; $\bigcirc$ cell 4 .

As it can be observed, the stationary response is obtained very rapidly, regardless of the flow rate used and an important decrease in the concentration of both types of pathogens is obtained. In less than 10 minutes, there are no appreciable changes in the concentration although dispersion of data informs about the complexity of the processes happening inside the cell. Anyway, a remarkable removal of 4-5 logs is obtained in every case. This removal is in agreement with other tests previously made with the same electrolyzer. Thus, Figure 4 summarizes the effect of this current charge applied on the disinfection attained as well as the effect of the flowrate (using additional data obtained in 9 different tests run with the same cells). As seen, the removal attained with these cells depends on the flowrate and current charge passed and it can be even as high as 7-8 logs.

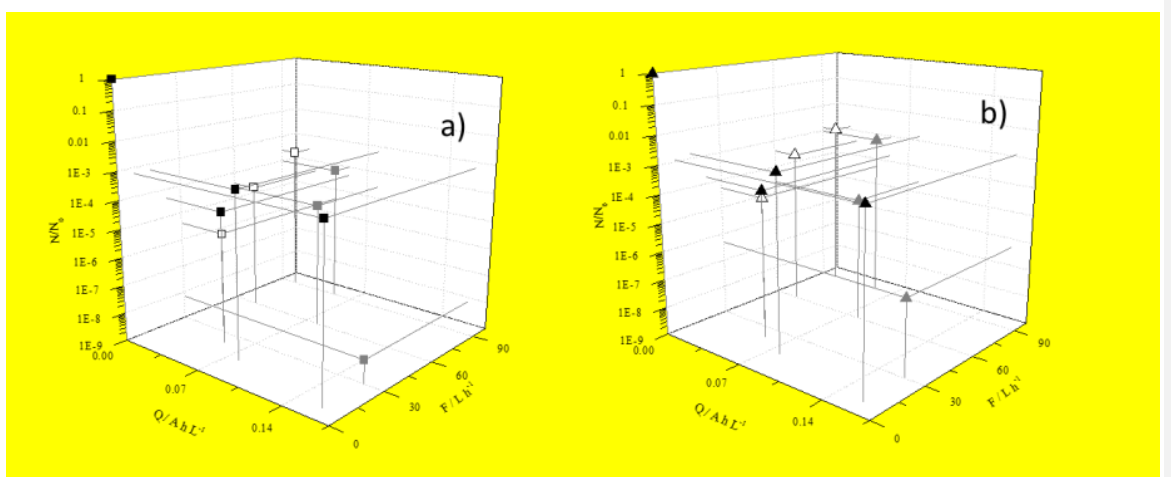

Figure 4. Removal of total coliforms (part a) and pseudomonas aeruginosa (part b) during the disinfection of water intensified with both pathogens at different flowrates and electric current charge passed. Empty symbols: 1 MIKROZON® operated at $30 \mathrm{~L} \mathrm{~h}^{-1}, 60 \mathrm{~L} \mathrm{~h}^{-1}$ and $90 \mathrm{~L} \mathrm{~h}^{-1}$; Degraded symbols: 4 MIKROZON® connected in series operated at $30 \mathrm{~L}$ 
h-1, $60 \mathrm{~L} \mathrm{~h}^{-1}$ and $90 \mathrm{~L} \mathrm{~h}^{-1}$; Full symbols: 4 MIKROZON® connected in parallel operated at 7.5 L h-1, $15 \mathrm{~L} \mathrm{~h}-1$ and $22.5 \mathrm{~L} \mathrm{~h}^{-1}$. Each cell was operated at the same current intensity of $1.2 \mathrm{~A}$.

Regarding the production of chlorates and perchlorates during operation of the electrodisinfection, it is shown in Figure 5 for the three tests carried out with four cells each. No perchlorates were detected in any of the tests and, as seen the concentrations of chlorates measured are very low (in particular when increasing the flowrate up to values close to the ones recommended by the manufacturer) with values below $5.0 \mu \mathrm{g} \mathrm{L}^{-1}$ of limit in the case of operating at $22.5 \mathrm{~L} \mathrm{~h}^{-1}$. Again, a high dispersion is obtained, being indicative of the many inputs that affect to the process performance and the difficulty of maintaining the same value of flowrate through all cells without the use of any control device.
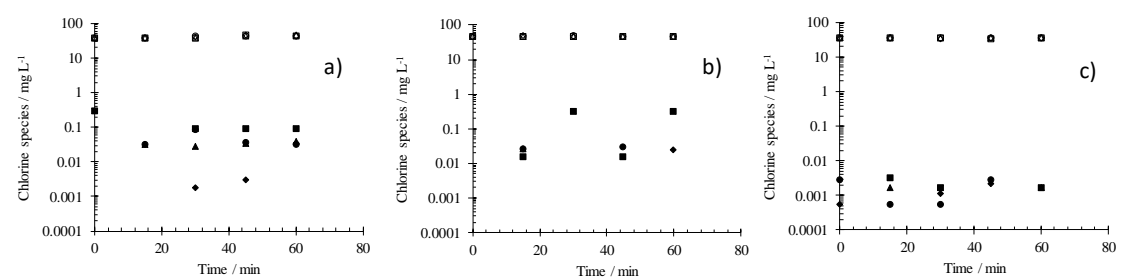

Figure 5. Time course of the concentration of ehlorine chloride (empty symbols) and chlorates (full symbols) during the disinfection of a) $7.5 \mathrm{~L} \mathrm{~h}^{-1}$; b) $15.0 \mathrm{~L} \mathrm{~h}^{-1}$; c) $22.5 \mathrm{~L} \mathrm{~h}^{-}$ ${ }^{1}$ of water.

$\boldsymbol{\square}$ cell $1 ; \bullet$ cell $2 ; \bullet$ cell $3 ; \boldsymbol{\Delta}$ cell 4 .

Figure 6 shows, in a 3-D plot, the influence of the current charge passed and flowrate on the generation of chlorates with these cells. Again, it is important to keep in mind that perchlorates have never been detected and that in using low residence times, results clearly indicate that prevention of chlorates formation down to reasonable levels can be 
achieved, with large flowrates and low current charges being very important to use. Anyway, the maximum concentration reached is lower than $30 \mu \mathrm{g} \mathrm{L}^{-1}$ and in most cases the value is under $5 \mu \mathrm{g} \mathrm{L}^{-1}$ and even undetectable by IC. It is important to note that the process is operated in continuous mode and that the data shown are steady-state data. In addition, it is important to see that initial concentration of chlorides is $50 \mathrm{mg} \mathrm{L}^{-1}$, meaning that less than $0.1 \%$ is transformed into the hazardous species chlorate or perchlorate.
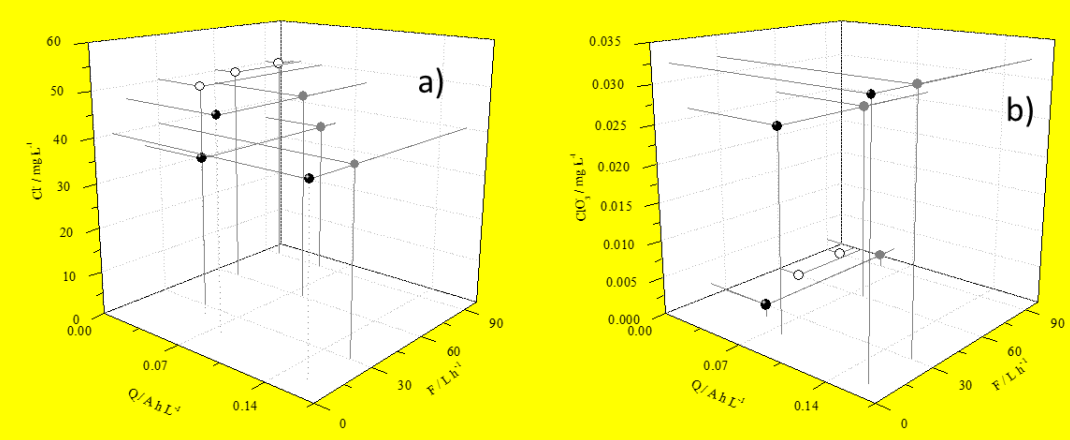

Figure 6. Production of chlorates and reduction of chlorides-Reduction of chloride (part a) and production of chlorate (part b) at different flowrates and electric current charge passed. Empty symbols: 1 MIKROZON® operated at 30 L h-1, 60 L h-1 and 90 L h-1 (section 5.1.2); Degraded symbols: 4 MIKROZON® connected in series operated at 30 L h-1, 60 L h-1 and 90 L h-1; Full symbols: 4 MIKROZON® connected in parallel operated at 7.5 L h-1, $15 \mathrm{~L} \mathrm{~h}-1$ and $22.5 \mathrm{~L} \mathrm{~h}-1$. Each cell was operated at the same current intensity of $1.2 \mathrm{~A}$.

In order to know more about the mechanisms, it was decided to carry out additional treatments in discontinuous mode (Figure 7). In this operation mode, water is recirculated through the reactor several times and it is expected that the oxidation of hypochlorite to chlorates and perchlorates will be more important, as compared to the results obtained in 
continuous mode and single pass. This is because the production of these two species is promoted by the interaction of the hydroxyl radicals formed on the surface of the diamond anodes and the hypochlorite according to the previously described eqs. 1 and 2 .

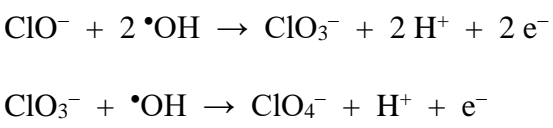

Because of the small dimensions of the MICROZON ${ }^{\circledR}$ cells and although the applied currents are within the recommended ranges, it is important to point out that the resulting current densities are extremely high. As seen, in general terms the same conclusions can be drawn from the results attained by operating in discontinuous mode although, it is very important to point out that the best results for the MICROZON ${ }^{\circledR}$ were obtained working at the lowest current densities.
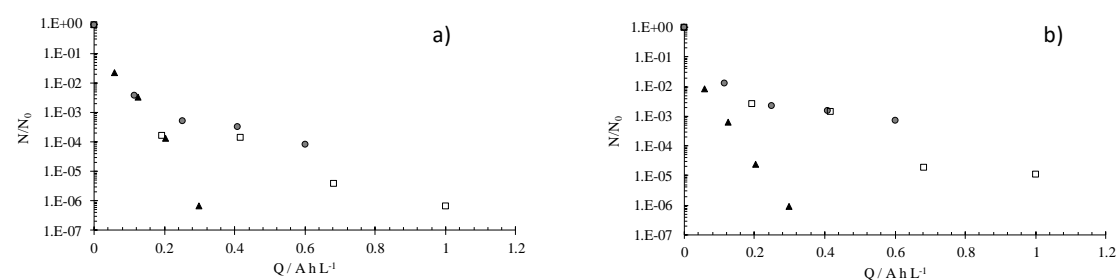

Figure 7. Removal of Total coliforms (part a) and pseudomonas aeruginosa (part b) with the MICROZON® cell: $\boldsymbol{\Delta} 0.3 \mathrm{~A} ; \bullet 0.6 \mathrm{~A} ; \square 1.0 \mathrm{~A}$

Equally important as the reduction of microorganisms, which followed the expected trend, is the chlorine speciation attained by the cell (shown in Figure 8). As expected [20, 21], the concentrations are higher than in continuous mode, although in any case the level of the ppm is reached. Hence, these data confirm that the low residence time in the cell (with the subsequent low contact time of the hypochlorite precursors and the hydroxyl 
radicals produced on the anode surface) is a key to attain an electro-disinfection with no or low production of chlorates, as it was the case for the tests performed in continuous mode. In this discontinuous mode, the MICROZON ${ }^{\circledR}$ produced a non-negligible amount of chlorates and perchlorates, a However, according to our hypothesis this result was to be expected due to the overall increased hydraulic residence time. An additional key point is the higher value of charge applied in the tests performed at discontinuous mode. Nevertheless, when all the results are analyzed together, it is worth noting that the concentration of chlorate is higher at discontinuous mode for the same disinfection degree, highlighting the key role of the mode of operation in the performance of the system.

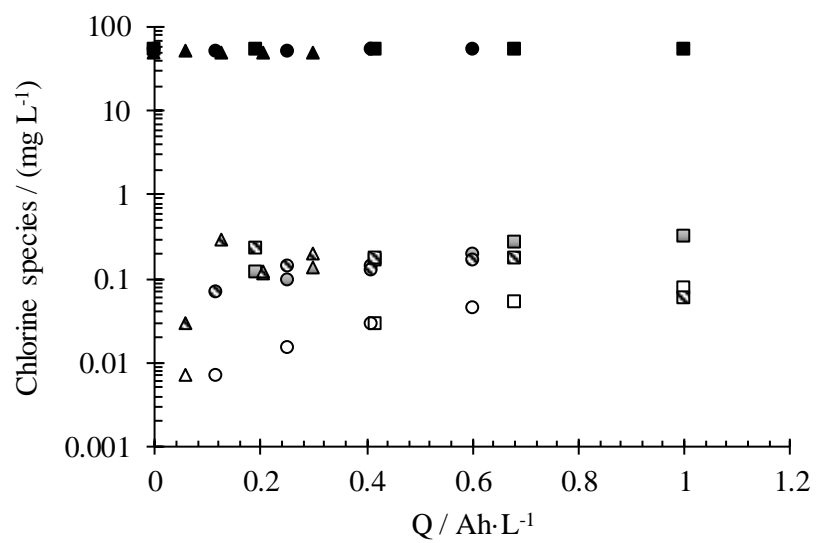

Figure 8. Speciation of chlorine during discontinuous electrolysis with MICROZON® cell chloride: full symbols; chlorate: empty symbols; perchlorate: degraded symbols; hypochlorite: dashed: $\boldsymbol{\Delta} 0.3 \mathrm{~A} ; \bullet 0.6 \mathrm{~A} ; \boldsymbol{\square} 1.0 \mathrm{~A}$

Hence, contact time of hypochlorite and electrode surface becomes a critical point in the use of this technology, although results presented in this work confirm the outstanding performance of the MICROZON ${ }^{\circledR}$ cells for disinfection. 
Additionally, a simulation of the hydraulic fluxes in the $\mathrm{MICROZON}^{\circledR}$ cell was carried out to confirm the role of the internal design of the cell. Figure 9 shows the hydrodynamics simulation of this cell at a flow rate of $1.1 \mathrm{~L} \mathrm{~min}^{-1}\left(66 \mathrm{~L} \mathrm{~h}^{-1}\right)$.

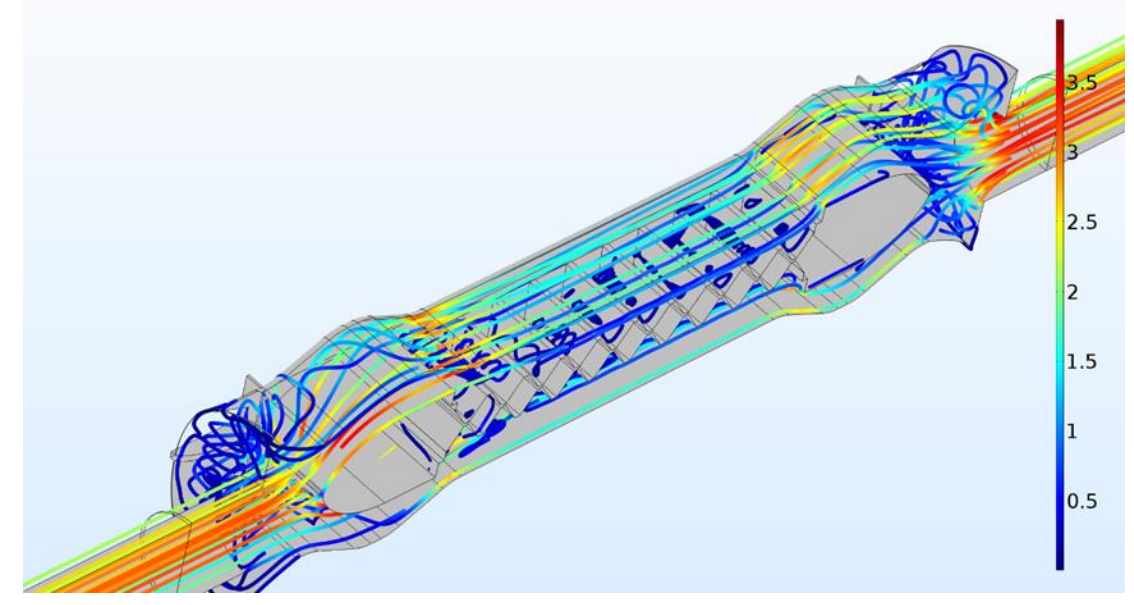

Figure 9. Hydrodynamics simulation of flow velocity $\left(\mathrm{m} \mathrm{s}^{-1}\right)$ inside the MICROZON ${ }^{\circledR}$ cell for a flow rate of $1.1 \mathrm{~L} \mathrm{~min}^{-1}\left(66 \mathrm{~L} \mathrm{~h}^{-1}\right)$.

As could be observed, the highest velocity is reached along the electrode meanwhile the lowest velocity is in the electrode trenches. Taking into account the hydraulic simulation, the low production of electrolysis by-products can be explained due to bypass of most volume. Moreover, the formation of small eddies in the channel helps to transport ozone away. That is, ozone bubbles should be quickly stripped off of surface

\section{Conclusions}

From this work, the following conclusions can be drawn:

- PEM electrolyzers can be successfully used to disinfect water, attaining removals of pathogens of several logs both in continuous and discontinuous operation mode. The percentage of removal depends on the flowrate used and the electric charge applied. 
- Although in general terms the results obtained by four cells are quite similar, dispersion informs about the complexity of these disinfection systems.

- The very low contact time of the electrode and water in the MICROZON ${ }^{\circledR}$ cell prevents the formation of chlorates. Only when this time is increased either by lowering the flowrate below the recommended values or by operating in discontinuous mode with several passes of the fluid through the cell, significant concentrations of chlorates are observed. Formation of perchlorates has not been observed with these cells in any case.

\section{Acknowledgments}

This research belongs to the SafeWaterAfrica project, funded by the European Union's

Horizon 2020 research and innovation program under grant agreement No 689925.

\section{References}

[1] C.A. Martinez-Huitle, E. Brillas, Electrochemical alternatives for drinking water disinfection, Angewandte Chemie-International Edition, 47 (2008) 1998-2005.

[2] R. Dewil, D. Mantzavinos, I. Poulios, M.A. Rodrigo, New perspectives for Advanced Oxidation Processes, J. Environ. Manage., 195 (2017) 93-99.

[3] P. Canizares, C. Saez, A. Sanchez-Carretero, M.A. Rodrigo, Synthesis of novel oxidants by electrochemical technology, Journal of Applied Electrochemistry, 39 (2009) 2143-2149.

[4] S. Velazquez-Pena, C. Saez, P. Canizares, I. Linares-Hernandez, V. Martinez-Miranda, C. Barrera-Diaz, M.A. Rodrigo, Production of oxidants via electrolysis of carbonate solutions with conductive-diamond anodes, Chemical Engineering Journal, 230 (2013) 272-278.

[5] C.A. Martínez-Huitle, M.A. Rodrigo, I. Sirés, O. Scialdone, Single and Coupled Electrochemical Processes and Reactors for the Abatement of Organic Water Pollutants: A Critical Review, Chemical Reviews, 115 (2015) 13362-13407.

[6] I. Sires, E. Brillas, M.A. Oturan, M.A. Rodrigo, M. Panizza, Electrochemical advanced oxidation processes: today and tomorrow. A review, Environmental Science and Pollution Research, 21 (2014) 8336-8367.

[7] M.I. Kerwick, S.M. Reddy, A.H.L. Chamberlain, D.M. Holt, Electrochemical disinfection, an environmentally acceptable method of drinking water disinfection?, Electrochimica Acta, 50 (2005) 5270-5277.

[8] C. Bruguera-Casamada, I. Sires, E. Brillas, R.M. Araujo, Effect of electrogenerated hydroxyl radicals, active chlorine and organic matter on the electrochemical inactivation of Pseudomonas aeruginosa using BDD and dimensionally stable anodes, Separation and Purification Technology, 178 (2017) 224-231. 
[9] S. Cotillas, J. Llanos, K. Castro-Rios, G. Taborda-Ocampo, M.A. Rodrigo, P. Canizares, Synergistic integration of sonochemical and electrochemical disinfection with DSA anodes, Chemosphere, 163 (2016) 562-568.

[10] G. Li, M. Zhu, J. Chen, Y. Li, X. Zhang, Production and contribution of hydroxyl radicals between the DSA anode and water interface, Journal of Environmental Sciences-China, 23 (2011) 744-748.

[11] N. Ngwenya, E.J. Ncube, J. Parsons, Recent Advances in Drinking Water Disinfection: Successes and Challenges, Reviews of Environmental Contamination and Toxicology, Vol 222, 222 (2013) 111-170.

[12] C.E. Schaefer, C. Andaya, A. Urtiaga, Assessment of disinfection and by-product formation during electrochemical treatment of surface water using a Ti/IrO2 anode, Chem. Eng. J., 264 (2015) 411-416.

[13] I. Sirés, E. Brillas, M.A. Oturan, M.A. Rodrigo, M. Panizza, Electrochemical advanced oxidation processes: today and tomorrow. A review, Environmental Science and Pollution Research, (2014).

[14] M.E.H. Bergmann, J. Rollin, T. lourtchouk, The occurrence of perchlorate during drinking water electrolysis using BDD anodes, Electrochimica Acta, 54 (2009) 2102-2107.

[15] M.E.H. Bergmann, T. lourtchouk, J. Rollin, The occurrence of bromate and perbromate on BDD anodes during electrolysis of aqueous systems containing bromide: first systematic experimental studies, Journal of Applied Electrochemistry, 41 (2011) 1109-1123.

[16] M.E.H. Bergmann, A.S. Koparal, T. lourtchouk, Electrochemical Advanced Oxidation Processes, Formation of Halogenate and Perhalogenate Species: A Critical Review, Critical Reviews in Environmental Science and Technology, 44 (2014) 348-390.

[17] M.E.H. Bergmann, T. lourtchouk, W. Schmidt, J. Hartmann, M. Fischer, G. Nuesske, D. Gerngross, Laboratory- and technical-scale comparison of chlorate and perchlorate formation during drinking water electrolysis: a field study, Journal of Applied Electrochemistry, 45 (2015) 765-778.

[18] S. Cotillas, M.J.M. de Vidales, J. Llanos, C. Sáez, P. Cañizares, M.A. Rodrigo, Electrolytic and electro-irradiated processes with diamond anodes for the oxidation of persistent pollutants and disinfection of urban treated wastewater, Journal of Hazardous Materials, 319 (2016) 93101.

[19] S. Cotillas, M.J. Martin de Vidales, J. Llanos, C. Saez, P. Canizares, M.A. Rodrigo, Electrolytic and electro-irradiated processes with diamond anodes for the oxidation of persistent pollutants and disinfection of urban treated wastewater, J. Hazard. Mater., 319 (2016) 93-101. [20] J. Isidro, J. Llanos, C. Saez, D. Brackemeyer, P. Canizares, T. Matthee, M.A. Rodrigo, Can CabECO (R) technology be used for the disinfection of highly faecal-polluted surface water?, Chemosphere, 209 (2018) 346-352.

[21] J. Isidro, J. Llanos, C. Saez, J. Lobato, P. Canizares, M.A. Rodrigo, Pre-disinfection columns to improve the performance of the direct electro-disinfection of highly faecal-polluted surface water, Journal of Environmental Management, 222 (2018) 135-140.

[22] A. De Battisti, P. Formaglio, S. Ferro, M. Al Aukidy, P. Verlicchi, Electrochemical disinfection of groundwater for civil use - An example of an effective endogenous advanced oxidation process, Chemosphere, 207 (2018) 101-109.

[23] M. Fryda, T. Matthee, Disinfecting system for low conductivity liquids, especially water, comprises electrochemical cell with electrodes for generating oxidants, with unit for thoroughly mixing the oxidants and liquid, in, Condias Gmbh; Fryda M; Matthee T.

[24] M. Fryda, B. Behrendt-Fryda, A. Hampel, L. Heesch, T. Matthee, M. Fischer, W. Schmidt, ELECTROCHEMICAL DISINFECTION WITH BORON DOPED DIAMOND ELECTRODES AND REDUCTION OF ELECTROLYSIS BY-PRODUCTS, Acs. Sym.Ser, (2016) 128-135.

[25] J. Isidro, D. Brackemeyer, C. Sáez, J. Llanos, J. Lobato, P. Cañizares, T. Matthee, M.A. Rodrigo, Operating the $\mathrm{CabECO}^{\circledR}$ membrane electrolytic technology in continuous mode for 
the direct disinfection of highly fecal-polluted water, Separation and Purification Technology, 208 (2019) 110-115. 